\title{
KARAKTERISTIK BRIKET DARI CAMPURAN LIMBAH KULIT PISANG DAN LIMBAH SERBUK GERGAJI
}

\author{
THE CHARACTERISTICS OF BRIQUETTE MADE FROM BANANA PEEL AND \\ SAWDUST MIXTURE
}

\author{
Sjamsiwarni Reny S \\ Balai Riset dan Standardisasi Industri Manado \\ Jalan Diponegoro No.21-23 Manado \\ Pos-el : Reny_sjarif@yahoo.co.id
}

\begin{abstract}
ABSTRAK
Kulit pisang dan serbuk gergaji merupakan limbah dari biomassa dapat diolah menjadi briket sebagai bahan bakar alternatif dengan tekanan, tanpa melalui proses karbonasi dan tidak menggunakan perekat. Tujuan dari penelitian untuk mengetahui karakteristik briket, dapat memanfaatan limbahdan juga mengurangi pencemaran lingkungan. Penelitian ini dilakukan dengan metode eksperimen. Bahan yang digunakan limbah kulit pisang raja, kulit pisang kepok dan serbuk gergaji. Penelitian pendahuluan pengujian bahan baku. Pembuatan briket dengan perbandingan bahan dasar $A=$ limbah kulit pisang raja : limbah serbuk gergaji(LKPR:LSG) $\left(A_{1}=90: 10, A_{2}=80: 20\right.$ dan $\left.A_{3}=70: 30\right)$ dan $B=$ Limbah kulit pisang kepok : limbah serbuk gergaji (LKPK:LSG) $\left(B_{1}=90: 10\right.$, $B_{2}=80: 20$ dan $B_{3}=70: 30$ ). Ukuran briket yang dihasilkan berdiameter 2 inci $\times 5 \mathrm{~cm}$ dengan ketebalan $3-4 \mathrm{~cm}$ dengan tekanan $100 \mathrm{~kg} / \mathrm{cm}^{2}$. Pengujian mutu dilakukan terhadap nilai kalori, kadar air, kadar abu dan bahan mudah menguap. Hasil pengamatan bahan baku kulit pisang raja memiliki nilai kalor $4404 \mathrm{kal} / \mathrm{g}$ dan nilai kalor pisang kepok $4250 \mathrm{kal} / \mathrm{g}$. Produk briket yang diperoleh setelah dilakukan perlakuan diperoleh pada LKPK; LSG $B_{3}(70: 30)$ yaitu $3985 \mathrm{kal} / \mathrm{g}$.

Kata kunci : Briket, kulit pisang dan serbuk gergaji
\end{abstract}

\section{ABSTRACT}

Banana peel and sawdust are organic wastes that can be processed into briquette as alternative fuel. The process was done with pressure, without carbonation and adhesive. The purpose of this research was to evaluate the briquette characteristics produced from waste to reduce pollution. This experimental research used banana dan sawdust waste. The briquette was prepared using various proportion of banana and sawdust as the following: $A=$ banana peel waste: sawdust waste (LKPK: LSG) $(A 1=90: 10, A 2=80: 20$ and $A 3=70: 30)$ and $B=$ banana peel waste: powder waste chainsaw (LKPK: LSG) $(B 1=90: 10, B 2=80: 20$ and $B 3=70: 30)$. The resulting briquette size is 2 inches $x 5 \mathrm{~cm}$ in diameter with $3-4 \mathrm{~cm}$ thickness with a pressure of $100 \mathrm{~kg} / \mathrm{cm}^{2}$. Quality testing is done on caloric value, moisture content, ash content and volatile matter. The observation of raw material of banana peel has a calorific value of $4404 \mathrm{cal} / \mathrm{g}$ and the calorific value of banana "kepok" $4250 \mathrm{kal} / \mathrm{g}$. The briquette product obtained after the was obtained at LKPK;LSG B3 (70:30) $3985 \mathrm{cal} / \mathrm{g}$.

Keywords: briquettes, banana peels and sawdust

\section{PENDAHULUAN}

Konsumsi bahan bakar setiap tahun meningkat dan terfokus pada penggunaan bahan bakar minyak dan gas yang berasal dari minyak bumi bersumber dari energi fosil yang tidak dapat diperbaharui (unrenewable) harganya semakin meningkat dan cadangannya semakin berkurang sehingga kita di haruskan mencari energi alternatif yang dapat diperbaharui (renewable). Usaha 
mengurangi dampak dari krisis energi dapat dilakukan melalui beberapa hal. Salah satunya dengan pengembangan energi biomassa dari limbah pertanian atau pemanfaatan limbah pertanian sebagai bahan bakar alternatif. Energi alternatif adalah energi yang terbarukan dan efisien untuk kebutuhan masyarakat, salah satu contohnya briket. Briket merupakan bahan bakar padat dan dapat dibuat dari biomassa yang mengandung karbon dengan nilai kalori yang cukup tinggi dan dapat menyala dalam waktu yang lama. Karbon mempunyai susunan kimia yang terdiri dari unsur karbon, hidrogen, oksigen dan komponen mineral non organis (1). Briket adalah bahan bakar yang lebih ramah lingkungan dan bahan bakunya lebih mudah didapat, prosesnya sederhana dan tidak mudah habis.

Menurut Ndraha, (2010), beberapa energi alternatif yang dapat dikembangkan sebagai pengganti dari minyak bumi adalah gas, batubara dan biomassa. Biomassa merupakan bahan alami yang biasanya dianggap sebagai sampah dan sering dimusnakan dengan cara dibakar (1).

Buah pisang merupakan salah satu produk buah unggulan nasional selain buah ini dikonsumsi mulai dari bayi hingga orang dewasa dan banyak pengolahan makan yang dapat dihasilkan dari buah pisang. Kulit pisang yang tergolong dalam biomassa meliputi hemiselulosa $38,1 \%$, lignin $58,5 \%$ dan selulosa 41,8\%(2).

Pada tahun 2010, produksi pisang di Indonesia mencapai 5,8 juta ton atau sekitar $30 \%$ dari produksi buah nasional. Luas panen tanaman pisang di Indonesia Tahun 2010 adalah sebesar 101.276 ha, dengan produksi 5.755 .73 ton dan produktifitas rata-rata 56,83 ton/ha (3).

Menurut Munadjim, (1983) (4), bagian yang dapat dimakan dari buah pisang adalah dua per tiga bagian dan satu per tiga bagiannya merupakan limbah pisang dan dibuang sebagai limbah organik Jumlah kulit pisang yang cukup banyak akan memiliki nilai yang menguntungkan apabila dapat dimanfaatkan sebagai bahan baku pembuatan briket sebagai bahan bakar alternatif yang dapat digunakan pada berbagai macam kebutuhan pengganti minyak tanah dan elpiji. Sehingga dapat memanfaatkan limbah kulit pisang untuk mengurangi pencemaran lingkungan sebagai bahan bakar alternatif berupa briket dengan mencampurkan limbah serbuk gergaji.

Serbuk gergajian adalah serbuk kayu dari jenis kayu apa saja yang diperoleh dari limbah atau pun sisa yang terbuang diperoleh dari tempat pengolahan kayu ataupun industri kayu. Menurut Syamsul Bahri (2007), (10) proses pengolahan kayu akan menghasilkan limbah 54,24\%,yang dihasilkan dari aktivitas pengolahan kayu adalah serbuk gergaji. Serbuk gergaji merupakan bahan yang dapat mengikat energi dan meningkatkan nilai kalor oleh karena itu rantai pelepasan energi diperpanjang. Pembuatan briket dengan menggunakan bahan dasar kulit pisang dan serbuk gergaji tanpa bahan perekat ini menghasilkan biobriket yang dapat digunakan sebagai alternatif dari pengganti bahan bakar fosil yang lebih ramah 
lingkungan. Tujuan penelitian ini untuk mengetahui karakteristik dari briket campuran limbah kulit pisang dan limbah serbuk gergaji.

\section{BAHAN DAN METODE}

\section{A. Bahan dan Alat}

Bahan yang digunakan dalam penelitian ini adalah: limbah kulit pisang raja, kulit pisang kepok diperoleh dari tempat penjualan gorengan, limbah serbuk gergaji diperoleh dari pengusaha/ pengrajin kayu, serta bahanbahan untuk analisis laboratorium.

Alat-alat yang digunakan terdiri dari: timbangan, ember bertutup, loyang besar, pengaduk, alat cetak briketpres hidrolik bertekanan $100 \mathrm{~kg} / \mathrm{cm}^{2}$, bom kalori meter, dan peralatan untuk analisis laboratorium.

\section{B. Metode Penelitian}

Penelitian ini dilaksanakan dengan metode eksperimen dengan dua tahap:
- Penelitian pendahuluan yaitu mengetahui nilai kalor bahan baku: limbah kulit pisang raja, pisang kepok dan limbah serbuk gergaji.

- Pembuatan adonan dengan 2 (dua) jenis pisang yaitu pisang raja, pisang kepok divariasikan dengan penambahan limbah serbuk gergaji sesuai perlakuan:

Limbah kulit Pisang Raja (LKPR)

Limbah Kulit Pisang Kepok (LKPK)

Limbah Serbuk Gergaji (LSG)

\section{$A=$ LKPR : LSG}

$\left(A_{1}=90: 10, A_{2}=80: 20\right.$ dan $\left.A_{3}=70: 30\right)$

$\mathbf{B}=$ LKPK : LSG

$\left(B_{1}=90: 10, B_{2}=80: 20\right.$ dan $\left.B_{3}=70: 30\right)$

\begin{tabular}{cccl} 
& Desain Penelitian & \\
\hline $\begin{array}{c}\text { Limbah Kulit Pisang } \\
\text { Raja(LKPR) : Limbah } \\
\text { Serbuk Gergaji(LSG) }\end{array}$ & $\begin{array}{c}\text { Limbah Kulit Pisang } \\
\text { Kepok (LKPK): Limbah } \\
\text { Serbuk Gergaji(LSG) }\end{array}$ & $\begin{array}{c}\text { Hasil Yang } \\
\text { diharapkan Bahan } \\
\text { Baku dan Produk }\end{array}$ & Proses \\
Briket & \multicolumn{1}{c}{ Brilai Kalor } & Tanpa \\
\hline $\mathrm{A}_{1} 90: 10$ & $\mathrm{~B}_{1} 90: 10$ & Kadar Air & Karbonasi \\
$\mathrm{A}_{2} 80: 20$ & $\mathrm{~B}_{2} 80: 20$ & Kadar Abu & Tanpa \\
$\mathrm{A}_{3} 70: 30$ & $\mathrm{~B}_{3} 70: 30$ & Kadar Volatil Matter & Perekat \\
\hline
\end{tabular}

\section{Prosedur Penelitian}

1. Persiapan bahan baku

Limbah serbuk gergaji dihaluskan dengan ukuran lolos ayakan 40 mesh. Limbah kulit pisang raja/ kepok yang akan digunakan dimasukkan dalam ember bertutup dan dibiarkan sampai \pm 10 hari (membusuk), sampai berubah warna hitam dan menjadi seperti bubur.

2. Pembuatan Adonan

Bahan baku limbah kulit pisang raja/ kepok yang sudah menjadi bubur dicampurkan dengan limbah serbuk gergaji sesuai dengan perlakuan.

3. Pencetakan 
Adonan yang telah dicampur, dicetak besi pipa $\varnothing 2 " \times 5 \mathrm{~cm}$ ) tebal $3-4 \mathrm{~cm}$ dengan menggunakan pres hidrolik tekanan $100 \mathrm{~kg} / \mathrm{cm}^{2}$, agar kepadatan briket dapat menyatu [13]

\section{Pengeringan}

Adonan yang sudah dicetak/ dibentuk dalam keadaan basah, sehingga perlu dikeringkan dengan menggunakan sinar matahari.

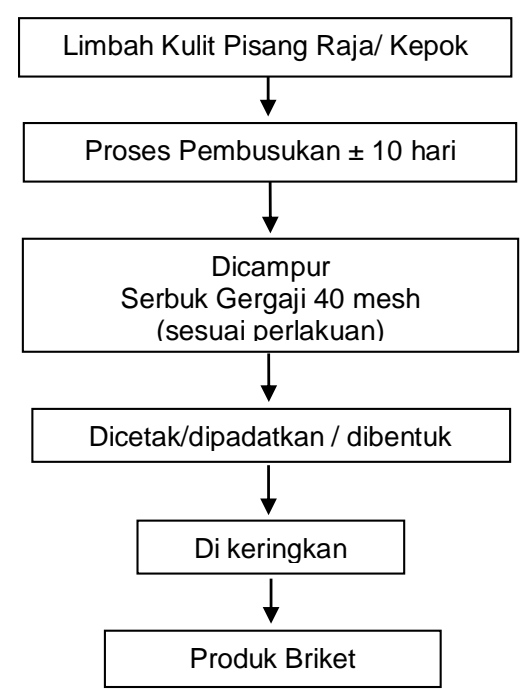

Gambar 1. Diagram alir proses pembuatan briket kulit pisang.

\section{HASIL DAN PEMBAHASAN}

\section{Analisis Bahan Baku yang Digunakan}

Tabel 1. Hasil analisis bahan baku kering limbah kulit pisang raja, pisang kepok dan limbah serbuk gergaji.

\begin{tabular}{lcccc}
\hline \multirow{2}{*}{ Bahan Baku Limbah } & \multicolumn{4}{c}{ Parameter Uji } \\
\cline { 2 - 5 } & $\begin{array}{c}\text { Nilai Kalor } \\
(\text { Kal/g) }\end{array}$ & $\begin{array}{c}\text { Kadar Air } \\
(\%)\end{array}$ & $\begin{array}{c}\text { Kadar abu } \\
(\%)\end{array}$ & $\begin{array}{c}\text { VM } \\
(\%)\end{array}$ \\
\hline Kulit Pisang Raja & 4402 & 6,30 & 4,26 & 90,04 \\
Kulit pisang Kepok & 4250 & 10,76 & 3,32 & 90,03 \\
Serbuk Gergaji & 4200 & 11,21 & 6,87 & 94,14
\end{tabular}

\section{Hasil Analisis Pada Tabel 1.}

Pada Tabel 1. menunjukkan nilai kalor dari bahan baku yang digunakan. Terlihat bahwa nilai kalor tertinggi dimiliki kulit pisang raja yaitu $4402 \mathrm{kal} / \mathrm{g}$, sedangkan nilai kalor terendah dimiliki dari bahan baku limbah serbuk gergaji yaitu $4200 \mathrm{kal} / \mathrm{g}$. Kulit pisang mengandung lignoselulosa serat yang terdiri 
dari selulosa yang dapat dijadikan bahan bakar.

\section{Kadar Air}

Kadar air bahan baku yang digunakan tertinggi dimiliki limbah serbuk gergaji 11,21 $\%$, sedangkan terendah kadar air dimiliki limbah kulit pisang raja yaitu 6,30\%. Kadar air yang tinggi menyulitkan penyalaan sehingga briket sulit terbakar. Serbuk gergaji menyerap air yang cukup tinggi. Hal ini sesuai dengan pernyataan Triono (2006) bahwa tingginya kadar air pada serbuk kayu gergaji disebabkan karena pada serbuk kayu gergaji memiliki jumlah poripori yang lebih banyak. Kandungan air yang tinggi pada briket juga akan menyulitkan penyalaan briket dan mengurangi temperatur pembakaran (Mislani \& Anugrah 2010)

\section{Kadar Abu}

Kadar abu bahan baku yang digunakan tertinggi dimiliki limbah serbuk gergaji 6,87\%, sedangkan terendah kadar abu dimiliki bahan baku limbah kulit pisang kepok yaitu 3,32\%. Semakin tinggi kadar abu secara umum akan mempengaruhi tingkat pengotoran, keausan dan korosif peralatan yang digunakan.

\section{Kadar Volatil Matter}

Kadar volatil meter bahan baku yang digunakan tertinggi dimiliki limbah serbuk gergaji $94,14 \%$, sedangkan yang terendah dimiliki bahan baku limbah kulit pisang kepok $90,03 \%$. Nilai ini sangat tinggi sehingga bahan ini cepat terbakar dan waktu penyalaan semakin singkat. Bahan baku ini baik digunakan untuk proses penyalaan.

\section{A. Hasil Uji Produk Briket}

Hasil uji produk briket limbah kulit pisang sesuai dengan perlakuan dapat dilihat pada grafik dibawah ini:

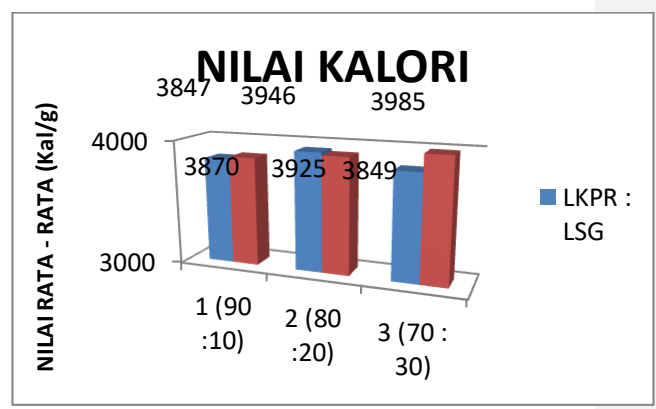

Grafik 1. Hasil uji nilai kalori

Nilai kalori merupakan hasil pembakaran atau karbonisasi dan jumlah karbon aktif atau karbon terikat dalam produk briket dengan oksigen dalam satu gram bahan atau produk briket (Mahmud,2010). Nilai kalor adalah energi kalor yang dapat dibebaskan oleh suatu bahan bakar dengan terjadinya reaksi/ proses pembakaran. Nilai kalor digunakan untuk mengetahui nilai panas pembakaran yang dapat dihasilkan oleh briket sebagai bahan bakar. Semakin tinggi nilai kalor yang dihasilkan oleh briket maka semakin baik mutu dan kualitasnya. (Faisal, 2014).Nilai kalor sangat dipengaruhi oleh semua komposisi kadar air, kadar abu dan zat terbang. Sehingga usaha-usaha untuk memperbaiki komposisi kandungan briket pasti akan menigkatkan nilai kalor briket. Hasil analisis nilai kalor pada Gambar 1. menunjukkan nilai tertinggi diperoleh dariproduk briket limbah LKPK: LSG dengan perlakuan $\mathrm{B}_{3} \quad(70: 30)$ yaitu $3985 \mathrm{kal} / \mathrm{g}$ sedangkan nilai kalor terendah diperoleh 
pada produk briket LKPR : LSG dengan perlakuan $A_{1}(90: 10)$ yaitu $3847 \mathrm{kal} / \mathrm{g}$. Limbah kulit pisang dan limbah serbuk gergaji memiliki nilai kalor yang mendekati sama antara 4200-4004 kal/g. Nilai kalor briket ini masih rendah bila dibandigkan dengan briket arang kayu $5000 \mathrm{kal} / \mathrm{g}(13)$ tapi dapat dijadikan sebagai bahan bakar alternatif untuk keperluan tertentu.

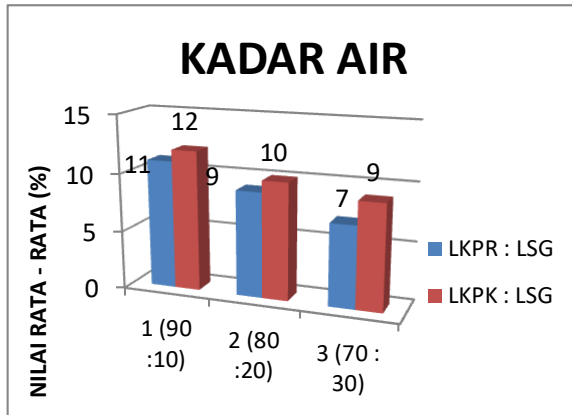

Gambar 2. Hasil uji nilai kadar air produk briket

Kadar air adalah jumlah air yang masih terdapat didalam briket setelah dilakukannya proses pengeringan atau pemanasan. Kadar air akan mempengaruhi mudah tidaknya briket tersebut untuk terbakar. Kadar air briket merupakan salah satu penentu kualitas briket. Jika briket mengandung banyak air maka briket sulit dinyalakan dan akan mengas ilkan banyak asap saat penyalaannya (Triono A,2006)

Hasil analisis pada Gambar 2 kadar air tertinggi diperoleh pada LKPK:LSG pada perlakuan $\mathrm{B}_{1}(90: 10)$ yaitu $12 \%$ dan kadar air terendah diperoleh pada LKPR:LSG perlakuan $\mathrm{A}_{3}$ (70:30) yaitu $7 \%$. Kadar air yang dimiliki produk briket cukup tinggi hal ini dikarenakan bubur limbah kulit pisang mempunyai kadar air yang tinggi $88 \%$. Kulit pisang dengan kadar air yang tinggi dicampurkan dengan serbuk gergaji yang bersifat higroskopis akan menyerap air dari limbah bubur dan akan tersimpan pada poripori serbuk gergaji sehingga hal ini sangat dipengaruhi dengan waktu pengeringan sehingga air yang terdapat pada briket belum menguap secara sempurna. Briket biomassa dengan proses karbonasi menghasilkan kadar air yang rendah dibandingkan dengan produk briket tanpa proses karbonasi yang memiliki kadar air lebih tinggi.

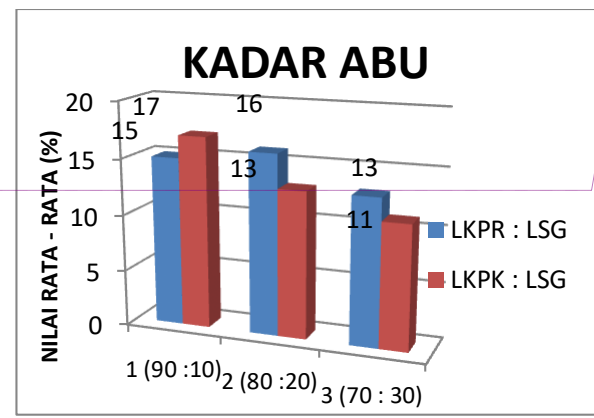

Grafik 3. Hasil uji nilai kadar abu produk briket

Abu yang terkandung dalam bahan bakar padat adalah mineral yang tidak dapat terbakar dan tertinggal setelah proses pembakaran selesai (Jumilatun) [11]. Abu berperan menurunkan mutu bahan bakar dengan menurunkan nilai kalor sehingga semakin tinggi kadar abu sebuah briket maka kualitas briket akan menurun. Kadar abu adalah persentase dari zat-zat yang tersisa dari proses pembakaran dan sudah tidak memiliki unsure karbon. Semakin tinggi kadar abu dalam suatu briket maka kualitas suatu 
briket akan semakin rendah karena kandungan abu yang tinggi dapat menurunkan nilai kalor. Hasil analisis pada Gambar 3. Kadar abu tertinggi diperoleh dari produk biket LKPK:LSG pada perlakuan $B_{1}$ $(90 ; 10)$ yaitu $17 \%$ dan terendah diperoleh pada produk briket LKPK:LSG perlakuan $B_{3}$ (70:30) yaitu 11\%. Nilai kadar abu pada briket dipengaruhi oleh komposisi bahan yang digunakan yaitu kulit pisang raja dan pisang kapok dan limbah serbuk gergaji.

Pada proses pengabuan, terjadi reaksi pembakaran dimana bahan bakar akan terbakar membentuk panas, uap air, dan karbondioksida. Briket campuran limbah kulit pisang dan limbah serbuk gergaji ini memiliki kandungan yang kompleks dimana didalamnya terdapat antara lain hemiselulosa $38,1 \%$, lignin $58,5 \%$ dan selulosa $41,8 \%$ (Erna R 2010) dan materi organik lainnya. Reaksi pembakaran yang terjadi pada bahan bakar padat secara umum adalah sebagai berikut:

Bahan bakar + $\mathrm{O} 2 \rightarrow$ gas buang + abu + panas

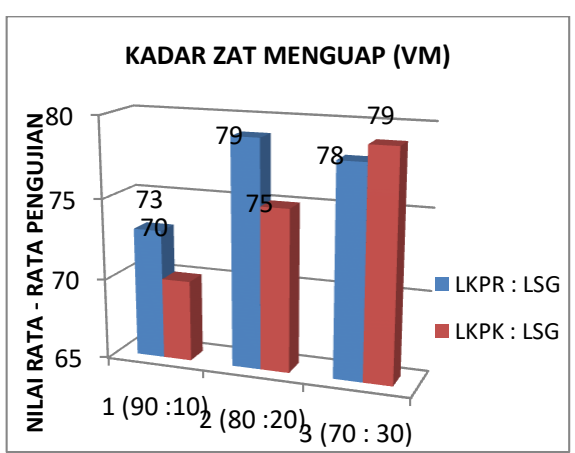

Grafik 4. Hasil Uji Nilai Kadar Mudah Menguap Produk Briket

Kadar zat mudah menguap atau Volatile Matter dalam bahan bakar berfungsi untuk stabilisasi nyala dan percepatan pembakaran briket. Semakin besar nilai volatile matter pada bahan bakar akan semakin cepat terbakar dan waktu penyalaan bahan bakar semakin singkat dan sebaliknya semakin kecil nilai volatile matter maka akan sulit dalam penyalaan awal bahan bakar briket. Kuncoro dkk. (1999) meneliti pembakaran briket tanpa karbonasi akan menyebabkan penyalaan briket menjadi mudah dibandingkan dengan briket yang telah dikarbonasi. Hal ini dikarenakan briket tanpa karbonasi masih mengandung kadar volattile matter yang cukup banyak. Berdasarkan hasil pengujian terhadap kadar zat menguap briket limbah kulit pisang nilai tertinggi zat mudah menguap pada produk briket LKPR:LSG pada perlakuan $A_{2} \quad(80: 20)$ dan briket LKPK:LSG perlakuan $B_{3}(70: 30)$ yaitu $79 \%$. Nilai kadar zat menguap terendah pada perlakuan LKPK:LSG $B_{1}(90: 10)$ yaitu $70 \%$. Zat mudah menguap pada briket ini dikarenakan kandungan VM bahan baku yang tinggi baik kulit pisang dan serbuk gergaji berkisar $90 \%$. Zat mudah menguap dalam briket ini bukan merupakan komponen penyusun arang tetapi merupakan hasil dekomposisi zat-zat penyusun arang akibat proses pemanasan (Perry dan Chilton,1973 dalam Dwiningsih 2006). Sehingga briket menghasilkan asap yang banyak kandungan volatil akan keluar dalam bentuk gas seperti: $\mathrm{CO}, \mathrm{CO} 2, \mathrm{CH} 4$ dan H2. Menurut Pengmei, dkk. (2004), komposisi gas selama devolatilisasi tergantung pada jenis bahan yang dibakar. Proses devolatilisasi diikuti dengan oksidasi bahan bakar padat yang 
lajunya tergantung pada konsentrasi oksigen, suhu gas, ukuran dan porositas arang (Syamsiro dan Saptoadi, 2004). Kenaikan konsentrasi oksigen dalam gas menimbulkan laju pembakaran lebih tinggi. Suhu pembakaran yang lebih tinggi dapat menaikkan laju reaksi dan menyebabkan waktu pembakaran menjadi lebih singkat. Volatile matter umumnya terdiri dari komposisi metane, hidrokarbons, hidrogen dan karbon monoksida, dan gas tidak mudah terbakar seperti karbondioksida dan nitrogen, berarti volatile matter bisa memudahkan proses pembakaran bio-briket atau sebaliknya, tergantung pada komposisi zat yang dikandungnya yang tidak bisa terbakar.(18)

\section{KESIMPULAN DAN SARAN}

Limbah kulit pisang dan limbah serbuk gergaji dapat diolah menjadi briket tanpa menggunakan perekat dan tidak melalui proses karbonasi digunakan sebagai bahan bakar alternatif dan mengurangi pencemaran lingkungan dari limbah ini. Produk briket dengan nilai kalori tertinggi pada LKPK:LSG perlakuan $B_{3}(70: 30)$ yaitu $3985 \mathrm{kal} / \mathrm{g}$, nilai kadar air terbaik pada produk briket dengan kadar air teredah pada LKPR:LSG $\mathrm{A}_{3}$ (70:30) yaitu $7 \%$, nilai kadar abu terendah pada produk briket LKPK:LSG perlakuan $\mathrm{B}_{3}(70: 30)$ yaitu $11 \%$ dan untuk Volatil Matter atau zat mudah menguap pada briket LKPK:LSG perlakuan $\mathrm{B}_{1}(90: 10)$ yaitu $70 \%$.

\section{DAFTAR PUSTAKA}

1. Apriati, 2008 Pemanfaatan Sampah Organik Sebagai Briket ,ITS Surabaya, jurusan teknik kimia.

2. Ndraha N,2010. "Uji komposisi bahan pembuat briket bioarang tempurung kelapa dan serbuk kayu terhadap mutu yang dihasilkan". Fakultas Pertanian. Universitas Sumatera Utara.

3. Erna R. 2010.Karakterisasi Briket Bioarang Limbah Pisang. J Teknik Kimia

4. Kuntarsih S. 2012.Pedoman Penanganan Pasca Panen Pisang. Kementrian Perindustrian.

5. Munajim.1983. Teknologi Pengolahan Pisang. Jakarta: Gramedia; 1983.

6. Bahri S. 2007.Pemanfaatan Limbah Industri Pengolahan kayu untuk pembuatan briket arang dalam mengurangi pencemaran lingkungan di Nangroe Aceh Darussalam. J Mek. 2007;vol.4 no.2:410-5.

7. Toni Taka, Apandi D. 1995. Rancang Bangun Mesin Pembriketan Batu Bara di Tegal, Jawa Tengah. Jawa Tengah.

8. Triono A. 2006. Karateristik Briket Arang dan campuran Serbuk Gergajian Kayu Afrika dan Sengon dengan Penambahan Tempurung Kelapa. Bogor.

9. Mislani

10.Mahmud N, 2010 Penentuan Nilai Kalori Berbagai Komposisi Bahan Bakar Minyak Nabati. Fakultas sains dan Teknologi, Jurusan Kimia, Universitas Islam Negeri Maulana Malik Ibrahim, Malang

11.Faizal. M,Andynapratiwi I,Destriana P.,2014.Pengaruh Komposisi Arang Dan Perekat Terhadap Kualitas Biobriket Dari Kayu Karet. No. 2, Vol. 20, April 2014.Teknik Kimia Universitas Sriwijaya. 
12.Nasional Badan Standardisasi. Briket Arang Kayu. SNI. SNI.01-623rd ed. Jakarta: BSN; 2000.

13.Jamilatun S.2008. Sifat- Sifat Penyalaan dan Pembakaran Briket Biomassa, Briket Batu Bara dan Arang Kayu. J

14.Rekayasa Proses, Vol 2 no 2,2008;2 No 2.

15.Kuncoro, H., Herbawamurti, T.E, Hawaria, Darmawan, 1999, Study On Coal Briquettes Stove In Indonesia, Energy Technology Laboratory, LSDE-BPPT, Jakarta.

16.Dwiningsih,A.2006. Pemanfaatan Serbuk Gergaji Kayu Sonokelin Dan Tempurung Kelapa Sebagi Briket.Skripsi S1 Jurusan Teknik Lingkungan. Universitas Islam Indonesia,Yogjakarta.

17.Pengmei Lv, Chang, J., Wang, T., dan Wu, C. A, 2004. Kinetic Study on Biomass Fast Catalytic Pyrolysis. Energy \& Fuels 18, 1865-1869.

18.Syamsiro, M. dan Harwin Saptoadi, 2007. Pembakaran Briket Biomassa Cangkang Kakao : Pengaruh Temperatur Udara Preheat, Seminar Nasional Teknologi 2007 (SNT 2007), Yogyakarta.

19.Yulia,y.S,Sri dan Ulfi,K 2017. Penentuan Kadar Air Hilang dan Volatile matter Pada Bio- Briket Dari Campuran Arang Sekam Pada dan Batok Kelapa. Jurnal IImu dan inovasi Fisika Vol.01,No 01(2017) 51-57 Departemen Fisika Fmipa Universitsa Padjajaran. Bandung. 
